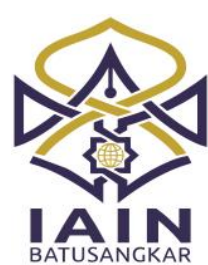

JURNAL TA'DIB, Vol 21 (2), 2018, (Juli-Desember)

ISSN : 1410-8208 (Print) 2580-2771 (Online)

Tersedia online di http://ecampus.iainbatusangkar.ac.id/ojs/index.php/takdib/index

\title{
PENGARUH TEKNIK MEMBACA SQ3R TERHADAP MEMBACA PEMAHAMAN MAHASISWA FKIP UNIVERSITAS BUNG HATTA PADANG
}

\section{Gusnetti*)}

Universitas Bung Hatta

Email : gusneti@bunghatta.ac.id

\section{Zaim}

Universitas Negeri Padang

Email: mzaim_unp@yahoo.com

\section{Syahrul R.}

Universitas Negeri Padang

Email:syahrulramadhan@gmail.com

\section{Agustina}

Universitas Negeri Padang

Email: tien agustina@yahoo.com

\begin{abstract}
Abstrak: The main issue discussed in this article is the students' low interest in reading textbooks. In addition, students do not use various techniques. As a result, they feel bored, and less concentrated when reading. The theory used in this research is the reading theory proposed by Tarigan (2008), reading comprehension techniques by Agustina (2008) and SQ3R reading techniques by Ermanto (2008) and Agustina (2008). This type of research is quantitative research using experimental method with SQ3R reading techniques. The population of this study were Indonesian Language and Literature Education students of FKIP Bung Hatta University who took the Reading Teaching Skills course. The sample was elected purposively. Based on data analysis, it was found that students did not apply the SQ3R reading technique well in determining the theme, plot, background, characterization, point of view and mandate, with an average value of 80.5. Thus, it can be concluded that there is a significant effect of the use of SQ3R reading techniques towards students' reading comprehension at FKIP of Bung Hatta University Padang.
\end{abstract}

Kata Kunci: SQ3R Reading Technique, Reading Comprehesion, Students of FKIP

\section{PENDAHULUAN}

S etiap orang yang sudah belajar tentu sering membaca, terutama dalam mengetahui sesuatu dalam bentuk tulisan, kegiatan membaca sangat diperlukan. Membaca melibatkan pikiran untuk memahami dan menginterpretasi lambang bahasa guna memperoleh informasi yang disampaikan penulis dalam tulisannya. Begitu juga dalam proses pembelajaran kegiatan membaca sangat diperlukan terutama membaca pemahaman. Tanpa melakukan membaca pemahaman seseorang akan sulit mema-hami materi pembelajaran yang dipelajarinya. Penelitian tentang membaca pemahaman sudah banyak para ahli mengungkapkannya seperti: Marzaban (2013), Stranovska (2014), Sidek ( 2015), Capellini (2015), Azizifar (2015), Balikcioglu (2016), Kamgar (2016), Olmez (2016) dan Zhussupova (20216) yang sependapat menga-takan bahwa pentingnya mengembangkan perilaku pada mahasiswa membaca pemahaman melalui penggunaan sumber daya atau strategi apapun. Selain itu mereka juga menjelaskan bahwa membaca itu merupakan kegiatan yang menutut pemahaman. Hal ini juga diungkapkan oleh Tarigan (2008: 7) bahwa membaca adalah suatu proses yang dilakukan oleh pembaca untuk menda-patkan pesan. Begitu juga Farida ( 2008: 2) bahwa membaca itu suatu 
kegiatan yang rumit yang meli-batkan banyak hal, tidak hanya sekadar melafalkan tulisan tetapi juga melibatkan aktivitas visual. Lain halnya dengan Agustina (2008:4) menjelaskan membaca juga merupakan kegiatan yang rumit serta mengindikasikan bahwa kemampuan membaca itu adalah kemampuan yang spesifik.

Dalam kegiatan proses pembelajaran, kegiatan membaca pemahaman sangat diperlukan dan harus dikuasai oleh mahasiswa. Dengan membaca pema-haman, mahasiswa akan mudah memahami dan mendapatkan informasi baik yang tersirat maupun yang tersurat. Kegiatan membaca pemahaman sangat diperlukan untuk meningkatkan mutu pendi-dikan sehinggga mahasiswa mampu memahami materi yang disampaikan pendidik. Menurut Agustina (2008: 15), membaca pemahaman yang dilakukan tanpa mengeluarkan bunyi atau suara, adalah suatu cara membaca agar mudah memahami suau bacaan dan mampu memahami apa yang dimaksudkan penulis dari tulisan yag dibuatnya baik secara tersirat maupun secara tersurat.

Teknik membaca pemahaman menurut Agustina (2008: 16-68) dan Zhussupova (2016) adalah memjawab pertanyaan, meringkas bacaan, mencari ide pokok, melengkapi paragraf, merumpangkan bacaan serta teknik memahami bacaan. Dengan menggunakan teknik membaca pemahaman mahasiswa akan dapat menentukan apa topik dari bacaan yang dibaca serta dapat menge-tahui sejauh mana pemahaman yang diperoleh mahasiswa dari aktivitas membaca yang dilakukannya.Hasil observasi terhadap mahasiswa menunjukkan bahwa mereka tidak menggunakan teknik membaca yang baik. Untuk dapat memahami bacaan dengan baik, digunakan salah satu teknik membaca SQ3R yaitu suatu moteode yang digunakan untuk membaca buku teks secara detail dan menyeluruh dari suatu bacaan yang dibaca.

Menurut Ermanto (2008: 88) penggunaan teknikmembaca SQ3R dalam rangka menemukan dan menguasai informasi secara detail dan menyeluruh pada buku teks dilakukan beberapa langkah, di antaranya: survei dulu bacaan yang akan dibaca dengan cara melihat judul, daftar isi serta sub bagian dari teks tersebut. Setelah itu ajukan pertanyaan dari subbab yang dibaca tadi apa isi dari bagian-bagiannya. Kemudian baca buku teks tersebut dengan konsentrasi yang penuh. Setelah selesai membaca, coba menjawab perta-nyaan yang telah dibuat tadi dengan tidak melihat ke bacaan yang telah dibaca. Setelah dapat men-jawab dengan baik, kemudian cek kembali dengan membaca kembali apakah jawaban yag diberikan tadi sesuai dengan pemahaman bacaan yang dibaca.

Berdasarkan teori di atas, maka penelitian ini akan melihat apakah ada pengaruh yang signifikan antara teknik membaca SQ3R terhadap membaca pemahaman mahasiswa FKIP Universitas Bung Hatta. Dengan hasil penelitian ini diharapkan bermanfaat dalam kegiatan pembelajaran terutama untuk mahasiswa sebagai bahan reverensi dalam membaca buku teks.

\section{METODE PENELITIAN}

Penelitian adalah menggunakan pendekatan kuantitatif dengan menggunakan metode deskriptif. Menurut Sugiono (2012: 7) penelitian kuantitatif adalah penelitian ilmiah karena telah memenuhi kaidah ilmiah yang empiris, objektif, terukur, rasional dan sistematis. Pada penelitian ini untuk melihat kemampuan membaca pemahaman mahasiwa dengan menggunakan teknik membaca SQ3R. 
Populasi peneliatian adalah seluruh maha-siswa Pendidikan Bahasa dan Sastra Indonesia angkatan 2015/2016 sebanyak 36 oranng. Menurut Arikunto (2012:113) purposif sampel merupakan pengambilan subjek bukan didasarkan atas strata, random atau daerah tetapi berdasarkan atas adanya tujuan tertentu. Penetapan sampel berdasarkan sampel penuh dari populasi. Instrumen penelitian berupa tes objektif sebanyak 60 soal untuk mengukur tingkat penguasaan kemampuan membaca pemahaman mahasiswa. Membaca pemahaman yang dianalisis mahasiswa adalah 6 buah teks pilkada.

Teknik pengumpulan data dengan memberikan 6 buah teks wacana Pilkada dengan teknik membaca SQ3R kepada mahasiswa Pendidikan Bahasa dan Sastra Indonesia FKIP Unversitas Bung Hatta Padang. Teknik pengum-pulan data yang ditetapkan adalah menjawab soal objektif sebanyak 60 soal yang terdiri Teks Pilkada 201810 soal, Pilkada seperti Peternakan Koruptor 10 soal, Tak Ada Satu Pilkada pun yang Tidak Curang 10 buah soal, PKS Sepakat untuk Mengembalikan Pilkada ke DPRD sebanayak 10 soal, Pro dan Kontra Wacana Pemilihan Kepala Daerah olleh DPRD sebanayak 10 soal dan Pilkada Lewat DPRD Dianggap bisa Kasus Korupsi sebanayak 10 soal. Analisis data dengan melakukan uji normalitas, uji homogenitas dan uji hipotesis.

\section{HASIL DAN PEMBAHASAN}

Data penelitian ini adalah data primer yaitu data yang diperoleh dari skor yang diambil dari jawaban mahasiswa dalam menjawab soal membaca pemahaman yang berbentuk objektif. Data tes akhir diambil dari hasil belajar dari membaca pemahaman sebanyak 6 buah wacana teks Pilkada.

\section{Hasil Belajar}

Kemampuan mahasiswa membaca pemahaman berdasarkan Teknik Membaca SQ3R yang digunakan adalah 79,63 dari 36 orang sampel. Nilai yang diperoleh mahasiswa berkisar dari 68 sampai 86 dengan kualifikasi baik. Mahasiswa yang mendapat nilai 86 berjumlah 1 orang, yang mendapat nilai 80 berjumlah 6 orang, yang mendapat nilai 78 berjumlah 2 orang, yang mendapat nilai 76 berjumlah 7 orang, yang mendapat nilai 74 berjumlah 7 orang, yang mendapat nilai 72 berjumlah 5 orang, yang mendapat nilai 70 berjumlah 3 orang dan siswa mendapat nilai 68 berjumlah 1 orang.

Berdasarkan hasil belajar membaca pemahaman teks Pilkada dengan menggunakan teknik membaca SQ3R, secara rinci dapat dibagi menjadi 5 kualisifikasi yaitu:1 orang siswa pada kualisifikasi sempurna, 4 orang berualisifikasi sangat baik, 15 orang berada pada kualisifikasi baik, 15 orang berkualifikasi lebih dari cukup dan 1 orang berkualifikasi cukup. Untuk lebih jelasnya dapat dilihat pada tabel di bawah ini

Tabel 1: Kalsifikasi Kemampuan Membaca Pemahaman dengan Menggunakan Teknik Membaca SQ3R Mahasiswa Program Studi Pendidikan Bahasa dan Sastra Indonesia FKIP Universitas Bung Hatta Padang

\begin{tabular}{|l|l|l|l|l|}
\hline $\begin{array}{l}\text { N } \\
\text { o. }\end{array}$ & $\begin{array}{l}\text { Tigkat } \\
\text { Penguas } \\
\text { aan }\end{array}$ & $\begin{array}{l}\text { Kualifik } \\
\text { asi }\end{array}$ & $\begin{array}{l}\text { Frekue } \\
\text { nsi }\end{array}$ & $\begin{array}{l}\text { Persent } \\
\text { ase }\end{array}$ \\
\hline 1 & $\begin{array}{l}85 \\
100 \%\end{array}$ & $\begin{array}{l}\text { Sempur } \\
\text { na }\end{array}$ & 1 & 2,78 \\
\hline 2 & $81-84 \%$ & $\begin{array}{l}\text { Sangat } \\
\text { Baik }\end{array}$ & 4 & 11,10 \\
\hline 3 & $76-80 \%$ & Baik & 15 & 41,67 \\
\hline 4 & $70-75 \%$ & $\begin{array}{l}\text { Lebih } \\
\text { dari } \\
\text { Cukup }\end{array}$ & 15 & 41,67 \\
\hline 5 & $65-69 \%$ & Cukup & 1 & 2,78 \\
\hline 6 & $60-64 \%$ & $\begin{array}{l}\text { Hampir } \\
\text { Cukup }\end{array}$ & 0 & 0 \\
\hline 7 & $55-59 \%$ & Kurang & 0 & 0 \\
\hline
\end{tabular}




\begin{tabular}{|l|l|l|l|l|}
\hline 8 & $45-54 \%$ & $\begin{array}{l}\text { Kurang } \\
\text { Sekali }\end{array}$ & 0 & 0 \\
\hline 9 & $\leq 44$ & Buruk & 0 & 0 \\
\hline & Jumlah & & 36 & 100 \\
\hline & & & & \\
\hline
\end{tabular}

Dari tabel di atas, dapat ditarik kesimpulan bahwa hasil belajar membaca pemahaman teks Pilkada dengan menggunakan teknik membaca SQ3R,mahasiswa Program Studi Pendidikan Bahasa dan Sastra Indonesia FKIP Universitasas Bung Hatta secara rinci dapat dibagi menjadi 5 kualisifikasi yaitu:1 orang siswa pada kualisifikasi sempurna, 4 orang berualisifikasi sangat baik,15 orang berada pada kualisifikasi baik, 15 orang berkualifikasi lebih dari cukup dan 1 orang berkualifikasi. Dengan demikian nilai ratarata mahasiswa Pendidikan Bahasa dan Sastra Indonesia baru berkualifikasi baik.

Perolehan hasil belajar mahasiswa FKIP Universitas Bung Hatta Padang dengan menggunakan Teknik Membaca SQ3R berdasarkan masing-masing teks.

Teks 1: Teks Pilkada 2018: Isu SARA dipredikisi aan kembali Panaskan Tensi .

Nilai kemampuan mahasiswa FKIP Universitas Bung Hatta Padang pada teks 1 berkisar antara $50-100$. Nilai rata-rata mahasiswa adalah 70,80. Mahasiswa yang mendapat nilai 100 sebanyak 2 orang, mahasiswa yang mendapat nilai 90 sebanyak 2 orang, mahasiswa yang mendapat nilai 80 sebanyak 8 orang, mahasiswa yang mendapat nilai 70 sebanyak 9 orang mahasiswa yang mendapat nilai 60 sebanyak dan mahasiswa yang mendapat nilai 50 sebanyak 1 orang,dan mahasiswa yang mendapat di bawah 50 tidak ditemukan. Untuk lebih jelasnya dapat dilihat pada tabel di bawah ini:

Tabel 2: Hasil Belajar Kemampuan Membaca Pemahaman Mahasiswa FKIP
Universitas Bung Hatta Padang Menggunakan Teknik Membaca SQ3R

\begin{tabular}{|l|l|l|l|l|}
\hline $\begin{array}{l}\text { No } \\
\cdot\end{array}$ & $\begin{array}{l}\text { Tigkat } \\
\text { Penguasaan }\end{array}$ & $\begin{array}{l}\text { Kualifika } \\
\text { si }\end{array}$ & $\begin{array}{l}\text { Frekue } \\
\text { nsi }\end{array}$ & $\begin{array}{l}\text { Persent } \\
\text { ase }\end{array}$ \\
\hline 1 & $85-100 \%$ & Sempurna & 4 & 11,11 \\
\hline 2 & $81-84 \%$ & $\begin{array}{l}\text { Sangat } \\
\text { Baik }\end{array}$ & 0 & 0 \\
\hline 3 & $76-80 \%$ & Baik & 8 & 22,22 \\
\hline 4 & $70-75 \%$ & $\begin{array}{l}\text { Lebih dari } \\
\text { Cukup }\end{array}$ & 12 & 33,34 \\
\hline 5 & $65-69 \%$ & Cukup & 0 & 0 \\
\hline 6 & $60-64 \%$ & $\begin{array}{l}\text { Hampir } \\
\text { Cukup }\end{array}$ & 11 & 30,36 \\
\hline 7 & $55-59 \%$ & Kurang & 0 & 0 \\
\hline 8 & $45-54 \%$ & $\begin{array}{l}\text { Kurang } \\
\text { Sekali }\end{array}$ & 1 & 2,77 \\
\hline 9 & $\leq 44$ & Buruk & 0 & 0 \\
\hline & Jumlah & & 36 & 100 \\
\hline
\end{tabular}

Berdasarkan data di atas, dapat ditarik kesimpulan bahwa rata-rata nilai kemampuan membaca pemahaman dengan menggunakan teknik membaca SQ3R mahasiswa Pendidikan bahasa dan Sastra Indonesia FKIP Universitas Bung Hatta Padang secara rinci dibagi menjadi 5 kualifikasi, yaitu kualifikasi sempurna sebanyak 4 orang ( $11,11 \%)$, berkualifikasi baik sebanyak 8 orang (22,22\%), berkualifikasi lebih dari cukup sebanyak 12 orang $(33,34 \%)$, berkualifikasi lebih dari cukup sebanyak 11 orang $(30,36 \%)$ dan berkulifikasi kurang sekali sebanyak 1 orang $(2,77 \%)$. Dengan demikian nilai rata-rata mahasiswa Pendidikan bahasa dan Sastra Indonesia FKIP Universitas Bung Hatta Padang baru berkualifikasi lebih dari cukup.

Teks 2: Pilkada seperti Peternakan Koruptor

Hasil belajar rata-rata diperoleh dari nilai kemampuan membaca pemahaman dengan menggunakan teknik membaca SQ3R mahasiswa Pendidikan bahasa dan Sastra Indonesia FKIP Universitas Bung Hatta Padang adalah 92, 60. Sebaran nili itu 
kisaran nilai adalah dari $60-100$. Mahasiswa yang mendapat nilai 100 sebanyak 22 orang, Mahasiswa' yang mendapat nilai 80 sebanyak 10 orang dan mahasiswa yang mendapat nilai 60 sebanyak 4 orang Untuk lebih jelasnya dapat dilihat pada tabel di bawah ini

Tabel 3 Hasil Belajar Nilai kemampuan FKIP Universitas Bung Hatta Padang degan Menggunakan Teknik Membaca SQ3R

\begin{tabular}{|l|l|l|l|l|}
\hline $\begin{array}{l}\text { N } \\
\text { o. }\end{array}$ & $\begin{array}{l}\text { Tigkat } \\
\text { Penguasaa } \\
\text { n }\end{array}$ & $\begin{array}{l}\text { Kualifi } \\
\text { kasi }\end{array}$ & $\begin{array}{l}\text { Frekue } \\
\text { nsi }\end{array}$ & $\begin{array}{l}\text { Persent } \\
\text { ase }\end{array}$ \\
\hline 1 & $85-100 \%$ & $\begin{array}{l}\text { Sempur } \\
\text { na }\end{array}$ & 22 & 61,11 \\
\hline 2 & $81-84 \%$ & $\begin{array}{l}\text { Sangat } \\
\text { Baik }\end{array}$ & 0 & 0 \\
\hline 3 & $76-80 \%$ & Baik & 10 & 26,78 \\
\hline 4 & $70-75 \%$ & $\begin{array}{l}\text { Lebih } \\
\text { dari } \\
\text { Cukup }\end{array}$ & 0 & 0 \\
\hline 5 & $65-69 \%$ & Cukup & 0 & 0 \\
\hline 6 & $60-64 \%$ & $\begin{array}{l}\text { Hampir } \\
\text { Cukup }\end{array}$ & 4 & 11,11 \\
\hline 7 & $55-59 \%$ & kurang & 0 & 0 \\
\hline 8 & $\begin{array}{l}45-54 \% \\
\text { Kurang } \\
\text { Sekali }\end{array}$ & 0 & 0 \\
\hline 9 & $\leq 44$ & Buruk & 0 & 0 \\
\hline & $\begin{array}{l}\text { Ju } \\
\text { m } \\
\text { la } \\
\text { h }\end{array}$ & \multicolumn{2}{|r|}{} & 100 \\
& & & \\
\hline
\end{tabular}

Dari data di atas, dapat ditarik kesimpulan bahwa rata-rata kemampuan membaca pemahaman mahasiswa Pendidikan bahasa dan Sastra Indonesia FKIP Universitas Bung Hatta Padang dapat diibagi menjadi 3 kualifikasi sempurna sebanyak 22 orang $(61,11 \%)$, berkualifikasi baik sebanyak 10 orang $(26,78 \%)$ dan berkualifikasi hampir cukup sebanyak 4 orang $(11,11 \%)$.yang. Dengan demikian nilai rata-rata kemampuan membaca pemahaman dengan menggunakan teknik membaca SQ3R mahasiswa Pendidikan bahasa dan Sastra Indonesia FKIP Universitas Bung Hatta Padang pada teks 2 adalah berkualifikasi sempurna

Teks 3: Tak Ada Satu Pilkada pun yang Tidak Curang

Hasil belajar kemampuan membaca pemahaman mahasiswa FKIP Universitas Bung Hatta Padang dalam memahami teks 3 nilai rata-rata adalah 93,40. Mahasiswa sudah dapat menjawab pertanyaan dengan sempurna . Hal ini telihat dari 36 orang siswa yang mendapat nilai 100 sebanyak 23 orang, mahasiswa yang mendapat nilai 80 sebanyak 9 orang dan mendapat nilai 60 sebanyak 4 orang. Untuk lebih jelasnya dapat dilihat pada tabel di bawah ini:

Tabel 4 Hasil Belajar Kemampuan Membaca Pemahaman Mahasiswa FKIP Universitas Bung Hatta Padang Menggunakan Teknik Membaca SQ3R

\begin{tabular}{|c|c|c|c|c|}
\hline $\begin{array}{l}\mathbf{N} \\
\text { o. }\end{array}$ & $\begin{array}{l}\text { Tigkat } \\
\text { Penguasaa } \\
\text { n }\end{array}$ & $\begin{array}{l}\text { Kualifi } \\
\text { kasi }\end{array}$ & $\begin{array}{l}\text { Frekue } \\
\text { nsi }\end{array}$ & $\begin{array}{l}\text { Persent } \\
\text { ase }\end{array}$ \\
\hline 1 & $85-100 \%$ & $\begin{array}{l}\text { Sempur } \\
\text { na }\end{array}$ & 23 & 63,89 \\
\hline 2 & $81-84 \%$ & $\begin{array}{l}\text { Sangat } \\
\text { Baik }\end{array}$ & 0 & 0 \\
\hline 3 & $76-80 \%$ & Baik & 9 & 25 \\
\hline 4 & $70-75 \%$ & $\begin{array}{l}\text { Lebih } \\
\text { dari } \\
\text { Cukup }\end{array}$ & 0 & 0 \\
\hline 5 & $65-69 \%$ & Cukup & 0 & 0 \\
\hline 6 & $60-64 \%$ & $\begin{array}{l}\text { Hampir } \\
\text { Cukup }\end{array}$ & 4 & 11,11 \\
\hline 7 & $55-59 \%$ & kurang & 0 & 0 \\
\hline 8 & $45-54 \%$ & $\begin{array}{l}\text { Kurang } \\
\text { Sekali }\end{array}$ & 0 & 0 \\
\hline \multirow[t]{2}{*}{9} & $\leq 44$ & Buruk & 0 & 0 \\
\hline & $\begin{array}{l}\mathrm{Ju} \\
\mathrm{m} \\
\mathrm{la} \\
\mathrm{h}\end{array}$ & & 36 & 100 \\
\hline
\end{tabular}

kesimpulan bahwa rata-rata nilai Nilai kemampuan mahasiswa Pendidikan bahasa dan Sastra Indonesia FKIP Universitas Bung 
Hatta Padang sudah sempurna sebanyak 23 orang $(63,89 \%)$ berkualifikasi baik sebanyak 9 orang $(25 \%$, dan berkualifikasi hampir cukup sebanyak 4 oarang (11,11\%.Dengan demikian nilai kemampuan mahasiswa Pendidikan bahasa dan Sastra Indonesia FKIP Universitas Bung Hatta Padang untuk menjawab soal teks 3 berkualifikasi sempurna

\section{Teks 4: PKS Sepakat untuk Setujui Pilkada Dikembalikan ke DPRD.}

Nilai kemampuan mahasiswa Pendidikan bahasa dan Sastra Indonesia FKIP Universitas Bung Hatta Padang dalam menjawam soal teks 4 berkisar dari nilai 60 - 90 . Mahasiswa yang mendapat nilaii 90 sebanyak 3 orang, mahasiswa yang mendapat nilai 80 sebanyak 13 orang, mahasiswa yang mendpat dilai 70 sebanyak 14 orang dan mahasiswa yaang mendapat nilai 60 sebanyak 6 orang. Untuk lebih jelasnya dapat dilihat pada tabel di bawah ini:

Tabel 5: Hasil Belajar kemampuan mahasiswa FKIP Universitas Bung Hatta Padang Menggu-nakan Teknik Membaca SQ3R untuk Teks 4

\begin{tabular}{|l|l|l|l|l|}
\hline $\begin{array}{l}\text { N } \\
\text { o. }\end{array}$ & $\begin{array}{l}\text { Tigkat } \\
\text { Penguasaa } \\
\text { n }\end{array}$ & $\begin{array}{l}\text { Kualifi } \\
\text { kasi }\end{array}$ & $\begin{array}{l}\text { Frekue } \\
\text { nsi }\end{array}$ & $\begin{array}{l}\text { Persent } \\
\text { ase }\end{array}$ \\
\hline 1 & $85-100 \%$ & $\begin{array}{l}\text { Sempur } \\
\text { na }\end{array}$ & 3 & 8,33 \\
\hline 2 & $81-84 \%$ & $\begin{array}{l}\text { Sangat } \\
\text { Baik }\end{array}$ & 0 & 0 \\
\hline 3 & $76-80 \%$ & Baik & 13 & 36,11 \\
\hline 4 & $70-75 \%$ & $\begin{array}{l}\text { Lebih } \\
\text { dari } \\
\text { Cukup }\end{array}$ & 14 & 38,89 \\
\hline 5 & $65-69 \%$ & Cukup & 0 & 0 \\
\hline 6 & $60-64 \%$ & $\begin{array}{l}\text { Hampir } \\
\text { Cukup }\end{array}$ & 6 & 16,67 \\
\hline 7 & $55-59 \%$ & kurang & 0 & 0 \\
\hline 8 & $45-54 \%$ & $\begin{array}{l}\text { Kurang } \\
\text { Sekali }\end{array}$ & 0 & 0 \\
\hline 9 & $\leq 44$ & Buruk & 0 & 0 \\
\hline & & & 36 & 100 \\
\hline
\end{tabular}

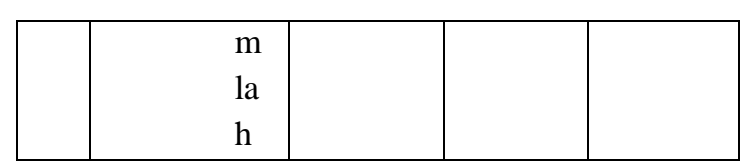

Dari data di atas, dapat ditarik kesimpulan bahwa rata-rata nilai kemampuan membaca pemahaman dalam menjawab soal teks 4 nilai rata-tata 71,90. Nilai yang dipeoleh dari kemampuan membaca pemahaman untuk teks 4 dapat dibagi menjadi 4 kualifikasi , yaitu kualifikasi sempurna senanyak 3 orang $(8,33 \%)$, berkualifikasi baik sebanyak 13 orang $(36,11 \%)$, berkualifikasi lebih dari cukup sebanyak 14 orang $(38,89 \%)$ dan berkualifikadi hampir cukup sebanyak 6 orang $(16,67 \%)$. Dengan demikian nilai rata-rata dalam menjawab soal teks 4 mahasiswa Pendidikan bahasa dan Sastra Indonesia FKIP Universitas Bung Hatta berkualifikasi lebih dari cukup

Teks 5: Pro dan Kontra Wacana Pemilihan Kepala Daerah oleh DPRD

Nilai kemampuan mahasiswa Pendidikan bahasa dan Sastra Indonesia FKIP Universitas Bung Hatta Padang Kemampuan berdasarkan teks 5 berkualifikasi lebih dari cukup dengan nilai rata-rata 71,10.Nilai kemampuan membaca pemahaman mahasiswa berkisar 60 - 90. Mahasiswa yang mendapat nniai 90 sebanyak 3 orang, mahasiswa yang mendapat nilai 80 sebanyak 11 orang,mahasiswa yang mendapat nilai 70 sebanyak 9 orang dan mahasiswa yang mendapat nilai 60 sebanyak 13 orang. Untuk lebih jelasnya dapat dilihat pada tabel di bawah ini:

Tabel 6 : Hasil Belajar Nilai kemampuan mahasiswa FKIP Universitas Bung Hatta Padang Menggunakan Teknik Membaca SQ3R

\begin{tabular}{|l|l|l|l|l|}
\hline No. & $\begin{array}{l}\text { Tigkat } \\
\text { Penguasa } \\
\text { an }\end{array}$ & $\begin{array}{l}\text { Kualif } \\
\text { ikasi }\end{array}$ & $\begin{array}{l}\text { Freku } \\
\text { ensi }\end{array}$ & $\begin{array}{l}\text { Persen } \\
\text { tase }\end{array}$ \\
\hline 1 & $85-100 \%$ & $\begin{array}{l}\text { Sempu } \\
\text { rna }\end{array}$ & 3 & 8,33 \\
\hline
\end{tabular}




\begin{tabular}{|l|l|l|l|l|}
\hline 2 & $81-84 \%$ & $\begin{array}{l}\text { Sangat } \\
\text { Baik }\end{array}$ & 0 & 0 \\
\hline 3 & $76-80 \%$ & Baik & 11 & 30,56 \\
\hline 4 & $70-75 \%$ & $\begin{array}{l}\text { Lebih } \\
\text { dari } \\
\text { Cukup }\end{array}$ & 9 & 25 \\
\hline 5 & $65-69 \%$ & Cukup & 0 & 0 \\
\hline 6 & $60-64 \%$ & $\begin{array}{l}\text { Hampi } \\
\text { r } \\
\text { Cukup }\end{array}$ & 13 & 36,11 \\
\hline 7 & $55-59 \%$ & kurang & 0 & 0 \\
\hline 8 & $45-54 \%$ & $\begin{array}{l}\text { Kuran } \\
\text { g } \\
\text { Sekali }\end{array}$ & 0 & 0 \\
\hline 9 & & Buruk & 0 & 0 \\
\hline & Ju & & 36 & 100 \\
ml & & & \\
\hline
\end{tabular}

Dari data di atas, dapat ditarik kesimpulan bahwa nilai kemampuan membaca pemahaman mahasiswa Pendidikan bahasa dan Sastra Indonesia FKIP Universitas Bung Hatta Padang dibagi menjadi 4 kualifikasi. Kualifikasi sempurna sebanyak 3 orang $(8,33 \%)$, berkualifikasi baik sebanyak 11 orang (30,56\%), berkualifikasi lebih dari cukup sebanyak 9 orang (25\%) dan berkualifikasi hampir cukup sebanyak 13 orang $(36,11 \%)$. Dengan demikian kemampuan membaca pemahaman mahasiswa Pendidikan bahasa dan Sastra Indonesia FKIP Universitas Bung Hatta Padang berkualifikasi blebih dari cukup.

\section{Teks 6: Pilkad Lewat DPRD Dianggap Bisa Kasus`Korupsi.}

Kemampuan membaca pemahaman mahasiswa Pendidikan bahasa dan Sastra Indonesia FKIP Universitas Bung Hatta Padang dalam menjawab soal teks 6 memperoleh nilai rata-rata 74,40. Sebaran nilai berkisar dari nilai 60 - 90. Mahasiswa yang mendapat nniai 90 sebanyak 3 orang, mahasiswa yang mendapat nilai 80 sebanyak 17 orang,mahasiswa yang mendapat nilai 70 sebanyak 9 orang dan mahasiswa yang mendapat nilai 60 sebanyak 7 orang. Untuk lebih jelasnya dapat dilihat pada tabel di bawah ini:

Tabel 7 : Hasil Belajar Kemampuan Membaca Pema-haman FKIP Universitas Bung Hatta Padang Menggunakan Teknik Membaca SQ3R

\begin{tabular}{|l|l|l|l|l|}
\hline $\begin{array}{l}\text { N } \\
\text { o. }\end{array}$ & $\begin{array}{l}\text { Tigkat } \\
\text { Penguas } \\
\text { aan }\end{array}$ & $\begin{array}{l}\text { Kualifik } \\
\text { asi } \\
100 \%\end{array}$ & $\begin{array}{l}\text { Frekue } \\
\text { nsi } \\
\text { na }\end{array}$ & $\begin{array}{l}\text { Persent } \\
\text { ase }\end{array}$ \\
\hline 1 & $86-95 \%$ & $\begin{array}{l}\text { Sangat } \\
\text { Baik }\end{array}$ & 0 & 0 \\
\hline 2 & $\begin{array}{l}\text { Sempur } \\
\text { Baik }\end{array}$ & 0 & 0 \\
\hline 3 & $76-85 \%$ & $\begin{array}{l}\text { Lebih } \\
\text { dari } \\
\text { Cukup }\end{array}$ & 4 & 18,18 \\
\hline 4 & $66-75 \%$ & \\
\hline 5 & $56-65 \%$ & Cukup & 0 & 0 \\
\hline 6 & $46-55 \%$ & $\begin{array}{l}\text { Hampir } \\
\text { Cukup }\end{array}$ & 0 & 0 \\
\hline 7 & $\begin{array}{l}36 \\
45 \%\end{array}$ & kurang & 0 & 0 \\
\hline 8 & $26-35 \%$ & $\begin{array}{l}\text { Kurang } \\
\text { Sekali }\end{array}$ & 0 & 0 \\
\hline 9 & $16-25 \%$ & Buruk & 0 & 0 \\
\hline & Jumlah & & 16 & 100 \\
\hline
\end{tabular}

Dari data di atas, dapat ditarik kesimpulan bahwa nilai kemampuan membaca pemahaman mahasiswa Pendidikan bahasa dan Sastra Indonesia FKIP Universitas Bung Hatta Padang dibagi menjadi 4 kualifikasi. Kualifikasi sempurna sebanyak 3 orang $(8,33 \%)$, berkualifikasi baik sebanayak 17 orang (47,22\%),berkualifikasi lebih dari cukup sebanyak 9 orang (25\%) dan berkualifikasi hampir cukup sebanyak 7 orang $(19,45 \%)$. Dengan demikian kemampuan membaca pemahaman mahasiswa. Pendidikan bahasa dan Sastra Indonesia FKIP Universitas Bung Hatta Padang berkualifikasi baik.

Berdasarkan analisis data di atas bahwa terdapat kemampuan membaca pemahaman denan menggunakan teknik membaca SQ3R 
mahasiswa Pendidikan Bahasa dan Sastra Indonesia FKIP Universitas Bung Hatta sudah baik. Dari data yang diperoleh kemampuan rata-rata yang mereka peroleh 79,03 .

Berdasarkan uji statistik diperoleh bahwa penerapan teknik membaca SQ3R dapat meningkatkan hasil belajar membaca pemahaman mahasiswa Pendidikan Bahasa dan Sastra Indonesia FKIP Universitas terjadi peningkatan, karena nilai ata-rata sebelum dilaksanakan dengan menggu-nakan tekik SQ3R hanya 67,77. Kumpulan nilai masing-masing teks dapat dilihat pada tabel di bawah ini

\begin{tabular}{|c|c|c|c|}
\hline No. & $\begin{array}{l}\text { Teks Membaca } \\
\text { Pemahaman }\end{array}$ & $\begin{array}{l}\text { Kualifikasi } \\
\text { Nilai }\end{array}$ & Nilai \\
\hline & $\begin{array}{lr}\text { Teks 1: } & \text { Teks } \\
\text { Pilkada } & \text { 2018: Isu } \\
\text { SARA } & \text { dipredikisi } \\
\text { aan } & \text { kembali } \\
\text { Panaskan Tensi }\end{array}$ & $\begin{array}{l}\text { Lebih dari } \\
\text { cukup }\end{array}$ & 70,80 \\
\hline & $\begin{array}{l}\text { Teks 2: Pilkada } \\
\text { seperti Peternakan } \\
\text { Koruptor }\end{array}$ & Sempurna & 92,60 \\
\hline & 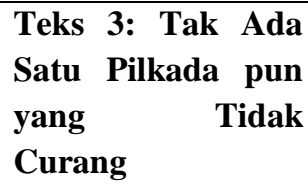 & Sempurna & 93,40 \\
\hline & $\begin{array}{lr}\text { Teks 4: } & \text { PKS } \\
\text { Sepakat rntuk } \\
\text { Setujui Pilkada } \\
\text { Dikembalikan ke } \\
\text { DPRD. }\end{array}$ & $\begin{array}{l}\text { Lebih dari } \\
\text { cukup }\end{array}$ & 71,90 \\
\hline & $\begin{array}{ll}\text { Teks 5: } & \text { Pro dan } \\
\text { Kontra } & \text { Wacana } \\
\text { Pemilihan } & \text { Kepala } \\
\text { Daerah oleh DPRD }\end{array}$ & $\begin{array}{l}\text { Lebih dari } \\
\text { cukup }\end{array}$ & 71,10 \\
\hline & $\begin{array}{lr}\text { Teks 6: } & \text { Pilkada } \\
\text { Lewat } & \text { DPRD } \\
\text { Dianggap } & \text { Bisa } \\
\text { Kasus' Korupsi. }\end{array}$ & $\begin{array}{l}\text { Lebih dari } \\
\text { cukup }\end{array}$ & 74,40 \\
\hline
\end{tabular}

Hasil penelitian ini sejalan dengan hasil penelitian (Permana, Sulistyowarni, \& Irmayanti, 2016; Dyahpuspita, 2015, Nurhayati, 2018; Sabarun, 2012)

KESIMPULAN DAN REKOMENDASI
Berdasarkan analisis data dan pembah asan tentang pengaruh penerapan teknik membaca SQ3R terhadap membaca pemahaman mahasiswa Pendidikan Bahasa dan Sastra Indonesia FKIP Universitas Bung Hatta Padang bahwa dengan menerapkan teknik membaca SQ3R dalam membaca pemahaman dapat meni gkatkan hasil belajar mahasiswa. Hal ini terlihat dari terjadinya peningkatan hasil belajar. Kesimpulan ini sekaligus merekomendasikan agar teknik ini digunakan untuk meningkatkan pemahaman membaca mahasiswa.

\section{REFERENSI}

Agustina. 2008. Pembelajaran Keterampilan Membaca . Padang:UNP Press

Arikunto.2010. Prosedur Penelitian. Jakarta: PT Rineka Cipta.

Atmazaki. 2009. Kiat-Kiat Mengarang dan Menyunting. Padang: UNP Press.

Azizifar, Akbar dkk. 2015. The Effect of Prereading Activities on The Readig Comprehension Performance of Ilami High School Sudent. 2nd Global Confrence on Linguistics anf Foregn Language Teaching LINELT-2014, Dubai- United Arab Emirates, December 11 - 132014.

Balickcioglu, Gulin \& Tuba Efe. 2016. The Role of Metacognitive Activies on University Level Preparatory Class EFL Learners Reading Comprehension. Turkey: International Co nfrence on Teaching annd Learning English as an Additional Language, GlobELT 2016, 14 - 17 April 2016, Antalya Turkey.

Capellini, Simone Aparecida dkk. 2015. Reading Comprehension Intervention 
Program for Teacher from 3 rd Grade Students. Barazil: Investigation of Learning Disabilities Laboratory of Speech and Hearing Science Department of Sao Paulo State University Julio de Mesquito. INTE 2014

Dyahpuspita, N. (2015). Pengaruh Metode SQ3R terhadap Kemampuan Membaca Pemahaman Siswa Kelas IV.2 SD Muhammadiyah Mutihan Tahun Ajaran 2014/2015.

Ermanto.2008. Keterampilan Membaca Cerdas. Padang: UNP Press

Gusnetti. 2005. Keterampilan Membaca. Padang: Bung Hatta University Press

Kamgar, Narges \& Esmaeil Jadidi. 2016. Exploring the Relationship of Iranian EFL Learners Critical Thinking and Self- Regulation with Their Reading Comprehension Ability. Turkey: International Co nfrence on Teaching annd Learning English as an Additional Language, GlobELT 2016, 14 - 17 April 2016, Antalya Turkey.

Nurhayati, S. (2018). Pengaruh Tehnik SQ3R (Survey, Question, Read, Recite, Review) terhadap Keterampilan Mebaca Pemahaman. Nuansa, 15(1).

Olmez, Funda. 2016. Exploring the Interaction of L2 Reading Comprehension with Text and LearnerRelated Factors. Turkey: International Co nfrence on Teaching annd Learning English as an Additional Language, GlobELT 2016, 14 - 17 April 2016, Antalya Turkey.
Ramadansyah. 2012. Paham dan Terampil Berbahasa da Bersastra Indonesia. Bandung: Dian Aksara Press.

Rahim, Farida. 2008. Pengajaran Membaca di Sekolah Dasar. Jakarta: PT Bumi Putra.

Marzban, Amir \& Ali Asqar Akbarnejad,2013. The Effect of Cooperative Reading Strategies on Improving Reading Comprehension of Iranian University Student. Iran: English Language Department Babol Mazanndaran Iran.. Akdeniz Lannuage Studies Confrence 2012.

Sabarun. (2012). Improving The Students' Reading Comprehension Ability through SQ3R Strategy. Journal on English as a Foreign Language, 2(1), 37-47.

Sidek \& Rahim. 2015. Rthe Role of Vocabulary Knowledge in Reading Comprehension: A Cross- Linguistic Study. Malaysia: Faculty of Mayor Languages Studies, Universiti Sains Islam Malysia (USIM). 7th World Confrence on Educational Science ( WCES-2015), 05-07 February 2015, Novotel Athens Convention Center, Athens Gree;

Stranovska, Eva dkk. 2014. Dynamics of reading Comprehension Skills in Linguistic Intervention Programme. Slovakia: LUMEN 2014

Sugiono 2010. Metode Penelitian Pendidikan. Bandung: Indonesia (IKAPI) 
Sugono. 2008. Kamus Besar Bahasa Tarigan, Henry Guntur. 2008. Membaca Indonesia Pusat Bahasa. Jakarta: PT Gramedia Pustaka Utama sebagai Keterampilan Berbahasa. Bandung: Angkasa.

\section{Article Metadata:}

Gusnetti. Zaim, M. R, Syahrul. Agustina. (2018). The Effect of SQ3R Reading Technique on the Reading Comprehesion of the Students of FKIP of Universitas Bung Hatta Padang. Ta'dib, 21 (2), 121-130 http://dx.doi.org/10.31958/jt.v21i2.1231

Keywords: SQ3R Reading Technique, Reading Comprehesion, Students of FKIP Coresponding author: Gusnetti, Universitas Bung Hatta, gusneti@bunghatta.ac.id 